Reprod. Nutr. Dévelop., 1980, 20 (1 B), 217-224.

\title{
Influence of experimental hypothyroidism on chick myogenesis
}

\author{
par F. BACOU, Monique JALLAGEAS*, J. NOUGUES, P. VIGNERON \\ Station de Physiologie animale, I.N.R.A. \\ E.N.S.A., place Vialo, 34060 Montpellier Cedex, France. \\ * Laboratoire de Neuroendocrinologie. Université de Montpellier II.
}

Summary. The influence on chick myogenesis of hypothyroid status induced in ovo by methimazole was histologically (number and types of muscle fibers) and biochemically studied. A single injection of methimazole induced an hypothyroid status during embryogenesis, as shown by the plasma $T_{4}$ levels which were separately assayed in male and female controls and treated embryos from day 12 of incubation to day 4 after hatching. In both sexes, control plasma $\mathrm{T}_{4}$ reached a peak on day 20 of incubation, but the female values were significantly higher ; plasma $T_{4}$ in the treated embryos remained at a low level independently of sex.

Only methimazole-treated males showed a significant increase $(P<0.01)$ in the total number of fibers of the two muscles (tibialis posterior and flexor digitorum) studied. Moreover, the histochemical results on succinate dehydrogenase and myofibrillar ATPase evidenced that, of the three fiber types $(\alpha R, \alpha W$ and $\beta R$ ) constituting the skeletal muscles, only the $\alpha$ fibers increased significantly.

Aldolase (glycolytic) and NADP isocitrate dehydrogenase (tricarboxylic acid cycle) activities, measured on the adductor and pectoralis muscles, showed a similar developmental pattern in control and treated animals, but was retarded in the latter due to a 5-day delay in hatching.

It is not known whether the tissular differences were related directly to the hypothyroid status, to alterations in nervous system differentiation or, as suggested by intersexual differences, to modifications in hormonal balance.

\section{Introduction.}

The muscle fibers of adult animals are classified into three main types according to their contractile and metabolic properties (Ashmore et al., 1972) : $\alpha \mathrm{W}$ (white fibers, fast twitch and glycolytic), $\alpha R$ (red fibers, fast twitch and oxidative) and $\beta R$ (red fibers, slow twitch and oxidative). The differences in these fibers, not apparent in the embryo, follow a pattern of incompletely known differentiation. Classical experiments on cross innervation have shown the importance of innervation in this differentiation and in the plasticity of muscular tissue (Buller et al., 1960). The role of hormones in deciding the phenotypic character of specific muscle proteins, as myosin, has been studied more these last few years than in the past (King and King, 1973 ; Van Hardeveld and Kassenaar, 1978). These studies have shown that alterations in the thyroid status result in 
significant changes in cardiac and skeletal muscle myosin, as in the fiber type pattern of muscular tissues (lanuzzo et al., 1977). However, most of these reports have concerned adult animals in which the tissues were already differentiated. During the course of embryogenesis, the interaction of muscular and nervous tissues with hormones may be different than those in the adult. We have studied the role of the thyroid hormone on myogenesis during embryonic life in the chick. By inhibiting thyroid activity during the prehatching period with methimazole (2-mercapto-1-methyl-imidazole), a thioamide as PTU, we obtained a new model system for carrying out histological, histochemical and biochemical studies on myogenesis.

\section{Material and methods.}

After a preliminary study (Goussopoulos et al., 1974), a single dose of methimazole (MMI) diluted in $250 \mu$ l of physiological serum was injected into the air cell of eggs at day 8 of incubation, that is a short time after thyroid activity was measurable (Thommes and Hylka, 1978). Hatching was retarded by 5 days.

a) Assay of plasma thyroxine levels in male and female embryos. - After one injection of MMI, the hypothyroid status was checked at different stages of embryonic life up to 25 days after the onset of incubation. Starting on day 12 of incubation, blood was collected by intra-cardiac puncture on sexed embryos in order to obtain separate male and female plasma samples. To avoid any interference with a possible circadian rhythm of $\mathrm{T}_{4}$ secretion, blood samples were always collected in the morning between 9 and 11 a.m. (Newcomer, 1974). According to the stages of incubation studied, equal volumes of plasma from 5 to 20 embryos were pooled and frozen at $-30^{\circ} \mathrm{C}$ before assay; each point of the $T_{4}$ curve (fig. 1) corresponds to the mean of 4 different pooled samples of embryonic plasma. $T_{4}$ was assayed according to Astier et al. (1978) from the original assay of Murphy et al. (1966) modified by Vigouroux (1972).

b) Choice and studies of muscular tissue. - The flexor digitorum and the tibialis posterior (mixed muscles) from 20-week old chicks were chosen and used for histological and histochemical analyses.

Histological study. After maceration of the muscle in a 20 p. 100 solution of nitric acid, parallel fiber bundles were separated and embedded in paraffin, then sectioned and stained with trioxyhematin and eosin. The total number of fibers in the two muscles were then counted using a Visopan Reichert projection microscope.

Histochemical study. The different fiber types of $m$. tibialis posterior $(\alpha R$ and $\beta R$ ) were determined histochemically. The red oxidative characteristics of the fibers were visualized by staining for succinate dehydrogenase (Nachlas, 1955); the $\alpha$ (fast) and $\beta$ (slow) types were determined with myofibrillar ATPase after alkali preincubation (Padykula and Herman, 1955) or acid preincubation (Brooke and Kaiser, 1969).

Enzyme analyses were assayed on glycolytic pectoralis muscle and oxidative adduclors of the thigh muscles during the perinatal period. The development of the specific metabolism of these muscles was studied with fructose 1-6 diphosphate aldolase (E.C. 4.1.2.13) and NADP isocitrate dehydrogenase (E.C. 1.1.1.42; ICDH). Enzymatic 
activities were recorded at $37^{\circ} \mathrm{C}$ on a spectrophotometer at $340 \mathrm{~nm}$ (light absorption by the coenzymes NAD and NADP). Total muscle proteins were measured according to the Folin-Lowry method (Lowry ef al., 1951).

\section{Results.}

Plasma $\mathrm{T}_{4}$ level did not markedly increase up to day 12 (Thommes ef al., 1977) ; if then rose rapidly up to day 20 , and more sharply in females than in males. Whatever the sex of the embryo, this level then dropped (fig. 1). MMI suppressed the peak of plasma $T_{4}$, which remained at a low level with a more pronounced minimum on day 18 in females than in males, and inhibited thyroid activity during the embryonic period when the plasma $T_{4}$ levels reach a sharp maximum.

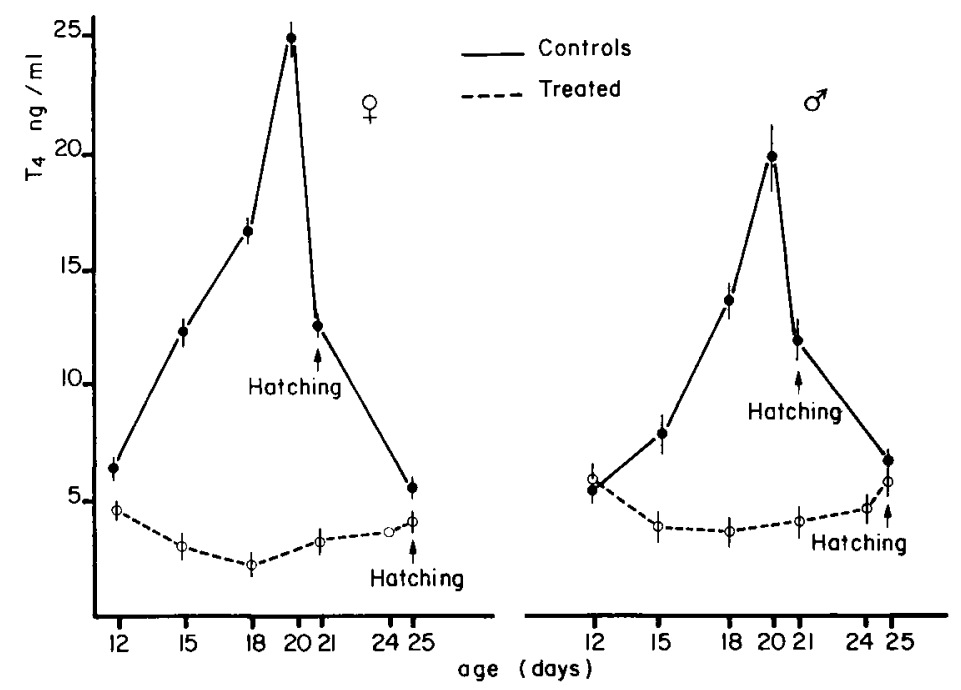

FIG. 1. - Pattern of plasma $T_{4}$ levels in male and female chick embryos : Effect of methimazole treatment.

On the other hand, muscle differentiation is most intense during this period: the fusion of myoblasts into myotubes progresses very rapidly and the myotubes are gradually transformed into fibers through structural modifications and the synthesis of specific muscular proteins. Figure $2 \mathrm{~A}$ shows that the oxidative ICDH activity increased in both muscles during the prenatal period, reaching a maximum at hatching. The glycolytic aldolase activity augmented 10 -fold only in the pectoralis after hatching, then stabilized (fig. 3A). Contrary to the results of lanuzzo et al. (1977) on the adult rat, these enzyme activities were very slightly disturbed in hypothyroidism. Enzymatic maturation was retarded only during the perinatal period (figs. 2B and $3 \mathrm{~B}$ ) ; this delay was undoubtedly related to the fact that hatching had been delayed. At that stage, plasma $T_{4}$ level was similar in treated and control chicks of both sexes. Furthermore, the muscles 
had attained their final number of fibers, varying with the species (Nouguès, 1972 ; Rowe and Goldspink, 1969).
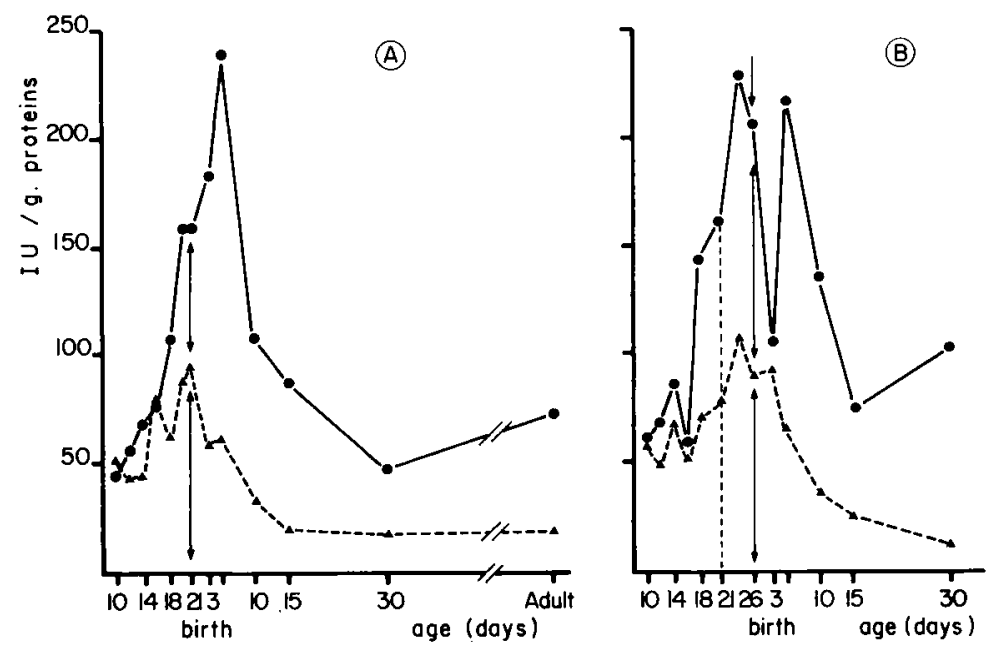

FIG. 2. - Effect of methimazole injected into the egg on NADP isocitrate dehydrogenase activity. A : control, : adductors, B : experimental ; ...... : pectoralis.
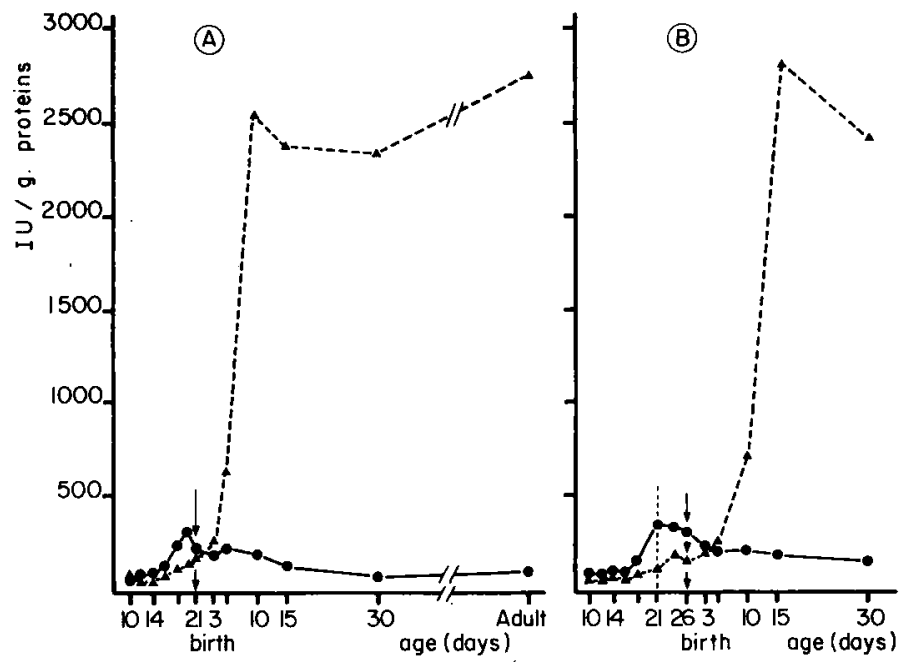

FIG. 3. - Effect of methimazole injected into the egg on aldolase activity. A : control, adductors, B : experimental ; - . . . - : pectoralis.

In ovo hypothyroidism induced a significant increase in the total number of fibers in the $\mathrm{m}$. tibialis posterior and the $\mathrm{m}$. flexor digitorum of 20-week old male chicks only (table 1); this would indicate a sex effect on the total number of fibers. The influence of $\mathrm{MMI}$ treatment on the $\mathrm{m}$. tibialis posterior (a muscle composed only of $\alpha \mathrm{R}$ and $\beta R$ fibers) 
was also observed at the histochemical level (table 2); the decrease in the number of $\beta R$ fibers in females was non-significant, while the number of $\alpha R$ fibers increased significantly. The number of $\beta R$ fibers in males did not change, but the number of $\alpha R$ fibers increased in the same manner as in the females. Since the total number of fibers was quite similar in hypothyroid and control females, the distribution pattern of muscular fibers must be different in that sex. On the other hand, the increase in the total number of fibers in treated males was due to the increment in the number of $\alpha R$ fibers.

\section{TABLE 1}

Effect of in ovo methimazole treatment on the fotal number of $m$. tibialis posterior and $m$. flexor digitorum fibers in 20-week old chicks

\begin{tabular}{|c|c|c|c|c|}
\hline \multirow{3}{*}{ Sex } & \multicolumn{4}{|c|}{ Muscles } \\
\hline & \multicolumn{2}{|c|}{ Tibialis posferior } & \multicolumn{2}{|c|}{ Flexor digitorum } \\
\hline & Control & Injected & Control & Injected \\
\hline 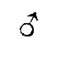 & $\begin{array}{c}15739 a \pm 609 \\
n=15\end{array}$ & $\begin{array}{c}18324^{a} \pm 634 \\
n=16\end{array}$ & $\begin{array}{c}9930^{b} \pm 470 \\
n=7\end{array}$ & $\begin{array}{c}11420^{b} \pm 256 \\
n=11\end{array}$ \\
\hline q & $\begin{array}{c}13547 \pm 464 \\
n=12\end{array}$ & $\begin{array}{c}14363 \pm 440 \\
n=14\end{array}$ & $\begin{array}{l}9030 \pm 393 \\
n=7\end{array}$ & $\begin{array}{c}9504 \pm 316 \\
n=11\end{array}$ \\
\hline
\end{tabular}

$\mathrm{n}=$ number of chicks.

All values are the mean $\pm S E$; means with a common superscript are significantly different $(P<0.01)$.

TABLE 2

Effect of in ovo methimazole treatment on $m$. tibialis posterior fiber types in 20-week old chicks

\begin{tabular}{|c|c|c|c|c|c|c|c|c|}
\hline \multirow{3}{*}{ Treatment } & \multicolumn{8}{|c|}{ Fibers } \\
\hline & \multicolumn{2}{|c|}{$\begin{array}{l}\text { Total number } \\
\text { of fibers }\end{array}$} & \multirow{2}{*}{$\frac{\text { p. } 100}{\sigma}$} & \multirow{2}{*}{$\frac{\text { fibers }}{q}$} & \multicolumn{2}{|c|}{$\begin{array}{l}\text { Number of } \\
\beta R \text { fibers }\end{array}$} & \multicolumn{2}{|c|}{$\begin{array}{l}\text { Number of } \\
\alpha R \text { fibers }\end{array}$} \\
\hline & 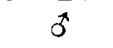 & O & & & 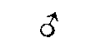 & P & $\delta$ & q \\
\hline Control & $\begin{array}{l}15806^{a} \\
n=5\end{array}$ & $\begin{array}{l}14466 \\
n=7\end{array}$ & $25,8^{b}$ & $18,15^{c}$ & 11549 & 12024 & $4257 d$ & $2442^{e}$ \\
\hline Injected & $\begin{array}{l}19068 a \\
\mathrm{n}=12\end{array}$ & $\begin{array}{l}14880 \\
n=9\end{array}$ & $39,7^{b}$ & $30,6^{c}$ & 11331 & 10239 & $7737 d$ & $4641=$ \\
\hline
\end{tabular}

$\mathbf{n}=$ number of animals.

Values with a common superscript are significantly different $(P<0.01)$.

\section{Discussion.}

The effects obtained at the histochemical level after injection of MMI were the consequence of the hypothyroid status induced during embryogenesis, as shown by the opposite results obtained after in ovo injection of $\mathrm{T}_{4}$ (Vigneron et al., unpublished data). 
Thyroid deficiency acts at several levels of the muscle structure. It modifies the relative proportions of different types of fibers, depending on the sex, because changes in muscle fiber type distribution in this study were different in females and males, particularly as concerned the number of $\beta R$ fibers which decreased in hypothyroid females but remained stable in males. Furthermore, the total number of fibers was modified by thyroid deficiency only in males as a consequence of two processes: an increase in the number of $\alpha R$ fibers and the relative stability of the number of $\beta R$ fibers. The stability of the total fiber number in females was only due to a redistribution of fiber types, leading to a different pattern of fiber composition. Both nervous and hormonal influences may explain these results.

A retarded development and a decreased ramification of motor nerve fibers during the formation of motor end plates might explain the larger $\alpha$-fiber population in treated animals. Kollros (1968) reported that treatment with thyroxine or antithyroid drugs induced an increase or a decrease, respectively, in the development of the lateral motor tracts in frog tadpoles. According to Sisto Daneo and Filogamo (1974), several myoblasts fuse with one myotube in some muscles near the nerve muscle contact area during the development of the focal innervation of $\alpha$-fibers, but not during the development of multi-innervated fibers, such as slow $\beta$-fibers. Thus, if the maturation of innervation is delayed, and myoblast fusion is inhibited, a higher myoblast population may result only when the myoblasts retain the status of dividing cells. This overpopulation of $\alpha$-type myoblasts might explain the later large increment of the same fiber type in male and female chicks treated in ovo with MMI.

The sex-linked differences may be understood from the data of Konigsberg (1958), Love et al. (1969) and De La Haba et al. (1968) who have shown that the endocrine system may control the speed of myoblast fusion as well as the rate of mitosis. The MMIinduced thyroid deficiency could act directly by inducing myoblast fusion via the disturbed hormonal balance. It is not known why this hormonal imbalance, which is different in males and females, modifies the appearance of type $\beta$ rather than type $\alpha$ fibers. The problem of myogenesis and the differentiation of several types of fibers remains to be solved. We know that during fiber type differentiation in fetal life, the $\beta$-type fibers appear first, the $\alpha$-type differentiating later in the periphery of the $\beta$ fibers (Ashmore et al., 1973). What are the relations between $\alpha$ and $\beta$ fibers during the course of development? Are these two fibers types genetically predelermined and thus vulnerable to the selective influences of the internal and external regulative factors of myogenesis? The questions raised by this study show that myogenesis is a complex problem; its regulation mechanisms, as those related to differentiation, are numerous. Their intricate relations do not allow a simple explanation or interpretation.

5e Réunion du groupe Développement I.N.R.A., Clermont-Ferrand/Theix, 17-18 mai 1979.

Acknowledgements. - We gratefully acknowledge the technical aid of Odette Moulierac, Marylène Rostagno and L. Marger, and the faithful help of J. Goussopoulos.

Résumé. L'influence d'un état hypothyroïdien induit in ovo par le méthimazole sur la myogenèse du poulet $a$ été étudiée par des techniques biochimiques et histochimiques (nombre et types de fibres musculaires). Une seule injection de méthimazole induit un état hypo- 
thyroïdien au cours de l'embryogenèse, comme le confirment les taux de $T_{4}$ plasmatique mesurés séparément chez les embryons mâles et femelles traités et témoins, depuis le douzième jour d'incubation au quatrième jour après l'éclosion. Dans les deux sexes, la thyroxinémie présente un pic au vingtième jour d'incubation, mais les valeurs sont significativement plus élevées chez les femelles; la thyroxinémie des embryons traités demeure à un faible niveau, indépendamment du sexe.

Le traitement au méthimazole induit, chez les mâles seulement, une augmentation significative $(\mathrm{p}<0,01)$ du nombre total des fibres dans les deux muscles étudiés (Tibialis posterior et Flexor digirorum). De plus, les activités histochimiques de la succinate dehydrogénase et de l'ATPase myofibrillaire montrent que, parmi les trois types de fibres $\alpha R, \alpha W$ et $\beta R$ qui constituent les muscles squelettiques, cette augmentation concerne principalement les fibres $\alpha$. Les activités de l'aldolase (glycolytique) ef de la NADP Isocitrate dehydrogénase (cycle de Krebs), mesurées sur les muscles Adductors et Pectoralis, ont un développement semblable entre animaux témoins et traités, mais décalé dans le temps en fonction des cinq jours de retard observés à l'éclosion.

L'origine des différences tissulaires observées demeure inconnue. Sont-elles liées directement à l'état hypothyroïdien, à des perturbations dans la différenciation du système nerveux ou, comme le suggèrent les différences intersexuelles observées, à des modifications de la balance hormonale?

\section{References}

ASHMORE C. R., TOMPKINS G., DOERR L., 1972. Postnatal development of muscle fiber types in domestic animals. J. Anim. Sci., 34, 37-41.

ASHMORE C. R., ADDIS P. B., DOERR L., 1973. Development of muscle fibers in the fetal pig. J. Anim. SCi., 36, 1088-1093.

ASTIER H. S., DANIEL J. Y., JALLAGEAS M., 1978. Estimation of plasma thyroxine concentration in ducks in relation to different environmental and experimental conditions. Experientia, 34, 1228-1229.

BROOKE M. H., KAISER K. K., 1969. Some comments on the histochemical method of adenosine triphosphatase. J. Histochem. Cytochem., 17, 431-432.

BULLER A. J., ECCLES J. C., ECCLES R. M., 1960. Interactions between motoneurones and muscles in respect of the characteristic speeds of their response. J. Physiol. London, 150, 417-439.

DE LA HABA G., COOPER G. W., ELTIN G., 1968. Myogenesis of striated muscles in vitro : hormones and serum requirements for the development of glycogene synthetase in myolubes. J. Cell Physiol., 72, 21-27.

GOUSSOPOULOS J., BACOU F., NOUGUĖS J., VIGNERON P., 1974. Effet du méthimazole injecté au cours de la vie embryonnaire sur le développement du poulet. 15th World Poultry Congr., New-Orleans, 509-510.

IANUZZO D., PATEL P., CHEN V., O'BRIEN P., WILLIAMS C., 1977. Thyroidal trophic influence on skeletal muscle myosin. Nature, London, 270, 74-76.

KING D. B., KING C. R., 1973. Thyroidal influence on early muscle growth of chickens. Gen. comp. Endocr., 21, 517-519.

KOLLROS J. J., 1968. Endocrine influences in neural development, 179-199. In Growth of nervous system Ciba Found. Symp., Churchill, London.

KONIGSBERG I. R., 1958. Thyroid regulation of protein and nucleic acid accumulation in developing skeletal muscle of chick embryo. J. cell. comp. Physiol., 52, 13-41.

LOVE D. S., STODDARD F. J., GRASSO J. A., 1969. Endocrine regulation of embryonic muscle development : Hormonal control of DNA accumulation, pentose cycle activity and myoblast proliferation. Dev. Biol., 20, 563-582.

LOWRY O. H., ROSEBROUGH N. J., FARR A. L., RANDAL R. J., 1951. Protein measurement with the folin phenol reagent. J. biol. Chem., 193, 265-275.

MURPHY B. E. P., PATTEE C. J., GOLD A., 1966. Clinical evaluation of a new method for the determination of serum thyroxine. J. clin. Endocr., 26, 247-256. 
NACHLAS M. M., TSOU K. C., De SOUZA E., CHENG C. S., 1955. Cytochemical demonstration of succinic dehydrogenase by the use of a new $\mathrm{p}$-nitrophenyl substituted ditetrazole. J. Histochem. Cytochem., 5, 420-436.

NEWCOMER W. S., 1974. Diurnal rhythms of thyroid function in chicks. Gen. comp. Endocr., 24, 65-73.

NOUGUĖS J., 1972. Etude de l'évolution du nombre des fibres musculaires au cours de la croissance postnatale du muscle chez le lapin. C. R. Soc. Biol., 166, 165-172.

PADYKULA H. A., HERMAN E., 1955. The specificity of the histochemical method for adenosine triphosphatase. J. Histochem. Cytochem., 3, 170-183.

ROWE R.W. D., GOLDSPINK G., 1969. Muscle fibre growth in five different muscles in both sexes of mice. I. Normal mice. J. Anat., 104, 519-530.

SISTO DANEO L., FILOGAMO G., 1974. Ultrastructure of developing myoneural junctions. Evidence for two patterns of synaptic area differentiation. J. Submicr. Cytol., 6, 219-228.

THOMMES R. C., HYLKA, 1978. Hypothalamo-adenohypophyseal-Thyroid. Interrelationships in the chick embryo. Gen. comp. Endocr., 34, 193-200.

THOMMES R. C., VIETH R. L., LEVASSEUR S., 1977. The effects of hypophysectomy by means of surgical decapitation on thyroid function in the developing chick embryo. l. Plasma thyroxine. Gen. comp. Endocr., 31, 29-36.

VAN HARDEVELD C., KASSENAAR A. A. H., 1978. Thyroid hormone uptake and $T_{4}$ derived $T_{3}$ formation in different skeletal muscle types of normal and hypothyroid rats. Acta. endocr. (Copenh.), 88, 306-320.

VIGOUROUX E., 1972. Radiodosage ultrasensible de la thyroxine par la méthode de compétition. $C$. R. Acad. Sci. Paris, Sér. D, 275, 579-582. 